Article

\title{
Giardia duodenalis associated with other gastrointestinal parasites in sheep in the North of the Brazilian state of Parana
}

Received: Aug, 2019; Accepted: Feb, 2020

\author{
Patricia Riddell Millar ${ }^{*}$, Adriana Pittella Sudré1, \\ Priscilla Fajardo Valente Pereira ${ }^{2}$, Bethânia Ferreira Bastos ${ }^{1}$, \\ Danuza Pinheiro Bastos Garcia de Mattos $^{1}$, Beatriz Brener ${ }^{1}$
}

\begin{abstract}
The sheep industry, an important economic activity in the Brazilian State of Parana, can be affected by gastrointestinal parasites. This study aimed to evaluate the occurrence of gastrointestinal parasites in sheep raised in the North of said state. Fecal samples were collected from 69 animals and processed through flotation and sedimentation. Parasites were found in 63 $(91.3 \%)$ animals. The most frequent parasites were strongylid eggs $(81.2 \%)$, followed by Eimeria sp (42\%) and Giardia duodenalis (10.1\%). To the best of our knowledge, this is the first report of Giardia duodenalis in sheep raised in the State of Parana. These findings indicate that sanitary management must be improved in order to control parasite infections and increase productivity.
\end{abstract}

Keywords: sheep; parasites; giardiasis; protozoa; helminths.

\section{Introduction}

Sheep farming is an activity widely exploited in tropical countries, where sheep are raised for their meat, milk and wool (Vieira, 2003). In developing countries, gastrointestinal parasitic diseases are one of the main

\footnotetext{
${ }^{1}$ Department of Microbiology and Parasitology, Instituto Biomédico, Universidade Federal Fluminense, Niterói, Rio de Janeiro, Brazil.

2 Department of Veterinary Studies-Centro de Ciências Agrárias, Universidade Estadual de Londrina, Londrina, Paraná, Brazil.

*Corresponding author: Universidade Federal Fluminense - Instituto Biomédico - Departamento de Microbiologia e Parasitologia - Rua Professor Ernani Melo, 101/ Sala 212-A - São Domingos, Niterói Rio de Janeiro - Brazil - 24210-130. Telefone: +55 2126292424 or +55 2126292425 . E-mail: patriciariddell@id.uff.br
} 
factors in herd productivity reduction (Amarante et al., 2004; Sweeny et al., 2012).

Sheep are usually raised in small overcrowded areas, which causes intense pasture contamination. Even in extensive breeding, gastrointestinal parasites can become a major problem when they are associated with malnutrition, management errors, and anthelmintic therapy inefficiency (Amarante et al., 2004; Sweeny et al., 2012).

Reduced productivity and mortality are directly related to helminthiasis in sheep (Amarante et al., 2004). The protozoan Giardia duodenalis is relevant in this context. This flagellate has been reported as the cause of diarrhea and decreased weight gain in lambs (Aloisio et al., 2006). In addition, the fact that domestic ruminants and other animals are sources of infection for humans has garnered the scientific community interest in animal giardiasis (Olson, et al., 1995; Feng; Chiao, 2011; Coelho et al., 2017).

To propose adequate control, knowledge of the main gastrointestinal parasites is essential, since the indiscriminate and repetitive use of different chemical treatments results in the selection of resistant parasite populations (Cunha Filho et al. 1998; Melo et al., 2003; Almeida et al., 2010). The objective of this study is twofold: 1) to provide the first report of Giardia duodenalis, and 2) investigate gastrointestinal parasitism by both helminths and protozoa in sheep raised in the North of the Brazilian State of Parana.

\section{Material and methods}

The study was conducted in the metropolitan area of Londrina, in the municipalities of Cambé $\left(23^{\circ} 16^{\prime} 33^{\prime \prime S}, 51^{\circ} 16^{\prime} 42^{\prime \prime W}\right)$ and Ibiporã (23ำ'09”S, $\left.51^{\circ} 02^{\prime} 53^{\prime} \mathrm{W}\right)$, both located in the north of Paraná State. The animals were 
raised in two different farms - Farm A (Cambé), and Farm B (Ibiporã) - and selected regardless of sex, age, and breed.

A questionnaire was used to collect the following data about the farms: source of water; nutritional, reproductive and sanitary management; facilities; type of raising; other domestic animals; individual aspects of each animal (i.e., age and sex). Data were collected by convenience sampling, with materials for coprological exams collected directly from the rectum (25 samples from Farm A; 44 from Farm B).

The fecal samples were chemically conserved in acetic formaldehyde solution and sent to the laboratory for further processing and analysis. They were examined for cestode, nematoid and intestinal protozoa through centrifugal flotation in zinc sulfate solution with density of $1.180 \mathrm{~g} / \mathrm{mL}$ (Faust et al, 1938) and spontaneous sedimentation (Hoffmann et al, 1934). Samples were examined in an optical microscope, and the parasites were morphometrically identified. It was not possible to perform fecal culture and oocyst sporulation due to the use of chemical conservation.

\section{Results and discussion}

A total of 69 sheep were studied (25 from Farm A, 44 from Farm B): 69.6\% (48) Santa Ines, 19.4 \% (12) Texel, 13.0\% (9) cross-breed (SI and 1/2 Texel). Ten animals (14.5\%) were younger than 6 months old while 59 (85.5\%) were adults, i.e., over 6 months old. All animals had good corporal score and normal feces.

Most animals $(91.3 \%$; 63) tested positive for parasites. The prevalence rates were 100\% (24/24) and 86.7\% (39/45) for Farm A and Farm B, respectively. This finding indicates a high occurrence of gastrointestinal parasites in sheep (91.3\%) in the region, one which is higher than reported by Souza et al. (2012) for sheep in the Northern State of Rio Grande do Norte $(76.56 \%)$. 
The sheep industry in Paraná State is concentrated in small areas, with high levels of pasture contamination (Nieto et al., 2003). Grasses of stoloniferous habit are traditionally used in Brazilian pastures for feeding sheep, which form a dense plant mass, preventing the direct incidence of sunlight and forming a microclimate that is favorable for the survival of helminth larvae and the viability of eggs and oocysts. This leads to a high infection rate, as observed in both properties in this study.

Polyparasitism was found in 30 (47.6\%) of the positive samples, and the most frequent association involved strongylid eggs and Eimeria sp. oocysts (Figure 1).

Figure 1: Polyparasitism in fecal samples of sheep raised in two farms located in the municipalities of Cambé (A) and Ibiporã (B) in the metropolitan area of Londrina, State of Parana, Brazil.

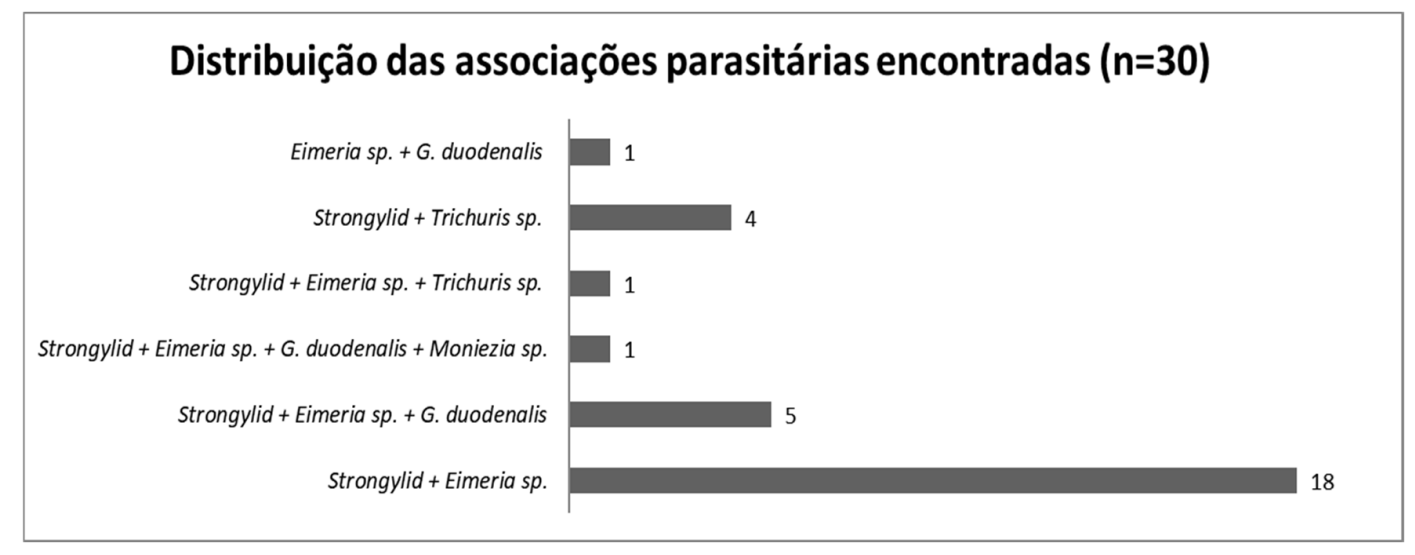

Table 1 provides the positive results distributed by farm and animal age. 
Table 1: Parasites identified in fecal samples of sheep raised in two farms located in the municipalities of Cambé (A) and Ibiporã (B) in the metropolitan area of Londrina, State of Parana, Brazil.

\begin{tabular}{ccccc}
\hline & \multicolumn{2}{c}{ Farm A } & \multicolumn{2}{c}{ Farm B } \\
\cline { 2 - 5 } Parasitism & Young $(<6$ months) & $\begin{array}{c}\text { Adult }(>6 \\
\text { months })\end{array}$ & $\begin{array}{c}\text { Young }(<6 \\
\text { months })\end{array}$ & $\begin{array}{c}\text { Adult }(>6 \\
\text { months })\end{array}$ \\
Strongylid & $6(100 \%)$ & $18(94.7 \%)$ & $3(75 \%)$ & N=40 \\
Trichuris sp. & 0 & 0 & $29(72.5 \%)$ \\
Moniezia sp. & $1(16.7 \%)$ & 0 & 0 & $4(10 \%)$ \\
Eimeria sp. & $6(100 \%)$ & $12(63.2 \%)$ & $2(50 \%)$ & $10(25 \%)$ \\
Giardiaduode & $5(83.3 \%)$ & 0 & $2(50 \%)$ & 0 \\
nalis & & & & \\
\hline
\end{tabular}

Strongylid eggs were the most frequent parasite as they were found in $56(81.2 \%)$ samples, followed by Eimeria sp. oocysts (29; 42\%). These findings are similar to those reported by Brito et al. (2009) in sheep in the Northern State of Maranhão: 63.54\% for helminth eggs and 58.85\% for Eimeria sp. oocysts. However, Souza et al. (2012) reported higher positivity for Eimeria sp. oocysts (56.25\%; 36/49), followed by strongylid eggs $(29.69 \% ; 19 / 49)$ in sheep in the State of Rio Grande do Norte. These differences may have been influenced by the diagnosis techniques, number of samples, geographic location, breed, time of the year, and environmental conditions (CARNEIRO et al., 2006; BASSETTO et al., 2009; McMANUS et al., 2009).

Most animals were female $(62 ; 89.9 \%)$. The majority of the females were in reproductive age, which may have contributed to the increased positive results, as pregnant and lactating females tend to have higher eggs per gram (epg) and oocyst elimination rate (see Amarante et al., 1992; Gauly et al., 2004). 
This is the first report to date of natural infection by Giardia duodenalis in sheep in the State of Parana, with a rate of $10.1 \%$ positive animals (7/69). This parasite was only found in young animals, which is probably related to their developing immune system and elimination of large numbers of cysts in the feces (Xiao; Herd, 1994; Koudela; Vitovec, 1998).

The analysis of a single sample may have underestimated the real prevalence of this protozoan, since studies have proved that cyst elimination is intermittent (Sweeny et al., 2011). Souza et al. (2012) reported 18.75\% (12/49) positive cases of Giardia duodenalis cysts in sheep in the State of Rio Grande do Norte. However, reports of this protozoan in sheep raised in Brazil are still scarce, which calls for further studies. Molecular studies could evaluate the real importance of these hosts as environmental contaminants and their potential risk for zoonotic transmission of this parasite.

Table 2 summarizes the differences in management and hygienic and sanitary conditions between the two farms. Farm sanitization must be performed systematically, with feces and food debris properly stored. Cleaning irregularities in Farm B may have favored the transmission of parasites that depend on infectious structures in the environment, such as Trichuris sp eggs, which were found in this farm. Thus, practices such as failing to quarantine the newly acquired animals and allowing the contact of the sheep with other ruminants, as observed in this property, may cause the transmission of parasites and increase the infection rate (Costa et al., 2011; Gouveia et al., 2013). 
Table 2: Hygienic, sanitary, and management conditions of two sheep farms located in the municipalities of Cambé (A) and Ibiporã (B) in the metropolitan area of Londrina, State of Parana, Brazil.

\begin{tabular}{|c|c|c|}
\hline Characteristics & Farm A & Farm B \\
\hline Creation system & Semi-intensive & Semi-intensive \\
\hline Production purpose & Meat production & Meat production \\
\hline Source of food & $\begin{array}{c}\text { Star grass and oats; } \\
\text { concentrate feed only for } \\
\text { ewes with newborns and } \\
\text { finishing lambs; mineral } \\
\text { supplementation in covered } \\
\text { trough } a d \text { libitum }\end{array}$ & $\begin{array}{l}\text { Brachiaria sp. and silage } \\
\text { provided in the trough; } \\
\text { provision of winter feed for } \\
\text { the entire herd; mineral } \\
\text { supplementation inside the } \\
\text { sheep pen ad libitum }\end{array}$ \\
\hline Source of water & Artesian well & Weir \\
\hline Antiparasitic treatment & Every 3 months & Monthly \\
\hline Type of facilities & Sheep pen with concrete floor & $\begin{array}{l}\text { Sheep pen with mud for most } \\
\text { animals. Sheep pen with } \\
\text { ripped floor for the finishing } \\
\text { lambs. }\end{array}$ \\
\hline Cleaning of facilities & $\begin{array}{l}\text { Daily, without chemicals, } \\
\text { only with mechanical } \\
\text { scraping }\end{array}$ & $\begin{array}{l}\text { Monthly, without chemicals, } \\
\text { only with mechanical } \\
\text { scraping }\end{array}$ \\
\hline Replacement animals & Yes & Yes \\
\hline $\begin{array}{c}\text { Quarantine of new } \\
\text { animals }\end{array}$ & Yes & No \\
\hline Sheep farming only & Yes & No, also bovine farming. \\
\hline $\begin{array}{l}\text { Contact with others } \\
\text { domestic animals }\end{array}$ & No & $\begin{array}{l}\text { Yes, contact between ovines, } \\
\text { bovines, shepherd dogs and } \\
\text { domestic birds. }\end{array}$ \\
\hline
\end{tabular}

The presence of domestic fowl and dogs in the farm B may also have contributed to the transmission of parasites, since these animals may be mechanical transmitters of parasitic structures (Traub et al., 2003; Majewska et al., 2009). Besides, dogs are hosts of zoonotic Giardia duodenalis genotypes, acting as a vessel of this protozoan. This fact contributes to environmental contamination, being a risk factor for 
parasite transmission (Bomfim et al., 2005; Sudré; Couto; Bonfim, 2012; Coelho et al., 2017).

The actual frequency of protozoa such as Giardia and Cryptosporidium is probably under diagnosed in the databases due to the parasitological techniques used in the routine control of small ruminants. Co-diagnostic methods allow greater sensitivity to research these agents in these animals. In addition, all animals in this study were asymptomatic, which may further contribute to the zoonotic risk of transmission.

The high infection rate and the report of Giardia duodenalis infection is indicative that improvement is necessary in the sanitary management of the animals under study. This may eventually result in reduced transmission rate, environmental contamination, and risks of human infection.

\title{
Conflict of interest
}

The authors declare that there is no conflict of interest.

\section{Ethics committee}

This study was approved by the Animal Ethics Committee of Universidade Federal Fluminense (CEUA-UFF), Approval No. 239, as of 9 August 2012.

\section{Ocorrência de Giardia sp associada à infecção por outros parasitos gastrointestinais em ovinos da região norte do estado do Paraná, Brasil}

\begin{abstract}
Resumo
A ovinocultura, uma atividade econômica muito importante no Estado do Paraná, pode ser afetada por parasitas gastrointestinais. O objetivo do presente estudo foi avaliar a ocorrência de parasitas gastrointestinais em ovinos criados na região norte do Paraná. Amostras fecais foram coletadas de 69 animais e processadas por técnicas de flutuação e sedimentação.
\end{abstract}


Encontraram-se parasitas em $63(91,3 \%)$ animais. Os parasitas mais freqüentes foram os ovos de estrongilideos (81,2\%), seguidos por Eimeria sp $(42 \%)$ e Giardia duodenalis (10,1\%). Até onde se pôde apurar, este é o primeiro relato de Giardia duodenalis em ovinos criados no Paraná. Esses resultados indicam que o manejo sanitário deve ser aprimorado para controlar infecções por esses parasitas e aumentar a produtividade.

Palavras-chave: ovinos; parasitas; giardíase; protozoários; helmintos.

\section{References}

ALMEIDA, F.A.; GARCIA, K.C.O.D.; TORGERSON, P.R.; AMARANTE, A.F.T. Multiple resistance to anthelmintics by Haemonchus contortus and Trichostrongylus colubriformis in sheep in Brazil. Parasitology International, Tokyo, v. 59, p.622-625, 2010. https://doi.org/10.1016/j.parint.2010.09.006

ALOISIO, F.; FILIPPINI, G.; ANTENUCCI, P.; LEPRI, E.; PEZZOTTI, G.; CACCIÒ, S.M.; POZIO, E. Severe weight loss in lambs infected with Giardia duodenalis assemblage B. Veterinary Parasitology, Amsterdam, v. 142, n.1-2, p.154-158, 2006. https://doi.org/10.1016/j.vetpar.2006.06.023

AMARANTE, A.F.T.; BARBOSA, M.A.; OLIVEIRA, M.; SIQUEIRA, E.R. Eliminação de ovos de nematódeos gastrintestinais por ovelhas de quatro raças durante diferentes fases reprodutivas. Pesquisa Agropecuária Brasileira, Brasília, v. 27, n. 1, p. 47-51, 1992.

AMARANTE, A.F.T.; BRICARELLO, P.A.; ROCHA, R.A.; GENNARI, S.M. Resistance of Santa Ines, Suffolk and Ile de France lambs to naturally acquired gastrointestinal nematode infections. Veterinary Parasitology, Amsterdam, v.120, p.91-106, 2004. https://doi.org/10.1016/j.vetpar.2003.12.004

BASSETTO, C.C.; SILVA, B.F.; FERNANDES, S.; AMARANTE, A.F.T. Contaminação da pastagem com larvas infectantes de nematoides gastrintestinais após o pastejo de ovelhas resistentes ou susceptíveis à verminose. Revista Brasileira 
de Parasitologia Veterinária, Jaboticabal, v.18, n.4, p.63-68, 2009. https://doi.org/10.4322/rbpv.01804012

BOMFIM, T.C.B.; HUBER, F.; GOMES, R.S.; ALVES, L.L. Natural infection by Giardia sp. And Cryptosporidium sp. in dairy goats, associated with possible risk factors of the studied properties. Veterinary Parasitology, Amsterdam, v.134, n. 1-2, p.9-13, 2005. https://doi.org/10.1016/j.vetpar.2005.05.067

BRITO, D.R.B.; SANTOS, A.C.G.; TEIXEIRA, W.C.; GUERRA, R.M.S.N.C. Parasitos Gastrintestinais em Caprinos e Ovinos da Microrregião do Alto Mearim e Grajaú, no Estado do Maranhão, Brasil. Ciência Animal Brasileira, Goiânia, v.10, n.3, p. 967974, 2009.

CARNEIRO, R.C.; SENO, M.C.Z.; RODRIGUES, C.F.C.; LEINZ, F.F.; BIANCHINI, D. Estudo da infecção helmíntica em cordeiros Suffolk submetidos a dois sistemas de terminação. Semina: Ciências Agrárias, Londrina, v.27, p.489-496, 2006. https://doi.org/10.5433/1679-0359.2006v27n3p489

COELHO, C.H.; DURIGAN, M.; LEAL, D.A.G.; SCHNEIDER, A.B.; FRANCO, R.M.B.; SINGER, S.M. Giardiasis as a neglected disease in Brazil: Systematic review of 20 years of publications. PLOS Neglected Tropical Diseases, v.11, p.1-23, 2017. https://doi.org/10.1371/journal.pntd.0006005

COSTA, V.M.M.; COSTA, V.M.M.; SIMÕE, S.V.D.; RIET-CORREA, F. Controle das parasitoses gastrintestinais em ovinos e caprinos na região semiárida do Nordeste do Brasil. Pesquisa Veterinária Brasileira, Rio de Janeiro, v.31,n.1, p.65-71, 2011. https://doi.org/10.1590/S0100-736X2011000100010

FAUST, E.C.; D'ANTONI, J.S.; ODOM, V.; MILLER, M.J.; PERES, C.; SAWITZ, W.; THOMEN, L.F.; TOBIE, J.; WALKER, J.H. A critical study of clinical laboratory technics for the diagnosis of protozoan cysts and helminth eggs in feces I. 
Preliminary communication. American Journal of Tropical Medicine, v.18, p.169-183, 1938. https://doi.org/10.4269/ajtmh.1938.s1-18.169

FENG, Y.; XIAO, L. Zoonotic potential and molecular epidemiology of Giardia species and giardiasis. Clinical Microbiology Reviews, v.24, n.1, p. 110-140, 2011. https://doi.org/10.1128/CMR.00033-10

GAULY, M.; REEG, J.; BAUER, C.; ERHARDT, G. Influence of production systems in lambs on the Eimeria oocyst output and weight gain. Small Ruminant Research, v.55, n.1, p.159-167, 2004. https://doi.org/10.1016/j.smallrumres.2004.02.001

GOUVEIA, A.M.G.; MOLENTO, M.B.; SILVA, M.X.; BRANDÃO, H.M.; GOUVEIA, G.C.; MORLÁN, J.B.; GUIMARÃES, A.S. Management practices to control gastrointestinal parasites in sheep farms in Minas Gerais, south eastern Brazil. Pesquisa Veterinária Brasileira, Rio de Janeiro, v.33, n.4, p.464-468, 2013. https://doi.org/10.1590/S0100-736X2013000400009

HOFFMAN, W.A.; PONS, J.A.; JANER, J.L. The sedimentation-concentration method in schistosomiasis mansoni. Puerto Rico Journal of Public Health and Tropical Medicine, Porto Rico, v.9, p.283-298,1934.

KOUDELA, B.; VITOVEC, J. Experimental giardiasis in goat kids. Veterinary Parasitology, Amsterdam, v.74, n.1, p.9-18, 1998. https://doi.org/10.1016/S0304$\underline{4017(97) 00146-5}$

MCMANUS, C.; LOUVANDINI, H.; PAIVA, S.R.; DE OLIVEIRA, A.A.; AZEVEDO, H.C.; DE MELO, C.B. Genetic factors of sheep affecting gastrointestinal parasite infections in the Distrito Federal, Brazil. Veterinary Parasitology, Amsterdam, v. 166, n.3-4, p.308-313, 2009. https://doi.org/10.1016/j.vetpar.2009.09.037

MELO, A.C.F.L.; REIS, I.F.; BEVILAQUA, C.M.L.; VIEIRA, L.S.; ECHEVARRIA, F.A.M.; MELO, L.M. Nematódeos resistentes a anti-helmíntico em rebanhos de 
ovinos e caprinos do estado do Ceará, Brasil. Ciencia Rural, Santa Maria, v.33, n.2, p.339-344, 2003. https://doi.org/10.1590/S0103-84782003000200024

NIETO, L.M.; MARTINS, E.M.; MACEDO, F.A.F.; ZUNDT, M. Observações Epidemiológicas de Helmintos Gastrintestinais em Ovelhas Mestiças Manejadas em Pastagens com Diferentes Hábitos de Crescimento. Ciência Animal Brasileira, Goiânia, v.4, n.1, p. 45-51, 2003.

OLSON, M.E.; MCALLISTER, T.A.; DESELLIERS, L.; MORCK, D.W.; CHENG, K.J.; BURET, A.G.; CERI, H. Effects of giardiasis on production in a domestic ruminant (lamb) model. American Journal of Veterinary Research, v.56, n.11, p.1470-1474, 1995.

SOUZA MF, PIMENTEL-NETO M, SILVA RM, FARIAS ACB, GUIMARAES MP. Gastrointestinal parasites of sheep, municipality of Lajes, Rio Grande do Norte, Brazil. Revista Brasileira de Parasitologia Veterinaria, Jaboticabal, v. 21, n.1, p.7173, 2012. https://doi.org/10.1590/S1984-29612012000100015

SUDRÉ, A.P.; COUTO, M.C.M.; BOMFIM, T.C.B. Occurrence of Giardia intestinalis in dairy goats and evaluation of risk factors for infection: research note. Revista Brasileira de Ciência Veterinária, Niterói, v.19, n.3, p.149-153, 2012 https://doi.org/10.4322/rbcv.2014.101

SWEENY, J.P.A.; RYAN, U.M.; ROBERTSON, I.D.; JACOBSON, C; WOODGATE, R.; Longitudinal investigation of protozoan parasites in meat lamb farms in southern Western Australia. Preventive Veterinary Medicine, v.101, n.3-4, p.192-203, 2011. https://doi.org/10.1016/j.prevetmed.2011.05.016

SWEENY, J.P.A.; ROBERTSON, I.D.; RYAN, U.M.; JACOBSON, C.; WOODGATE, R.G. Impacts of naturally acquired protozoa and strongylid nematode infections on growth and fecal attributes in lambs. Veterinary Parasitology, Amsterdam, v.184, p.298-308, 2012. https://doi.org/10.1016/j.vetpar.2011.08.016 
TRAUB, R.J.; ROBERTSON, I.D.; IRWIN, P.; MENCKE N, MONIS P. THOMPSON, R.C. Humans, dogs and parasitic zoonoses - unraveling the relationship in a remote endemic community in northeast India using molecular tools. Parasitology Research, v.90, S156-S157, 2003. https://doi.org/10.1007/s00436-003-0925-3

VIEIRA, L.S. Alternativas para o controle da verminose gastrintestinal dos pequenos ruminantes. Circular Técnica 29 online. ISSN 0100-9915. EMBRAPA, Ministério da Agricultura, Pecuária e Abastecimento, 2003.

XIAO, L.; HERD, R.P. Infection pattern of cryptosporidium and Giardia in calves. Veterinary Parasitology, Amsterdam, v.55, n.3, p.257-262, 1994. https://doi.org/10.1016/0304-4017(93)00645-F 